\title{
Non-Immigrant Labor Policy in the United States
}

\author{
Vernon M. Briggs, Jr.
}

The employment of foreign workers as a supplement to the domestic labor force has been a recurrent public policy issue throughout much of the history of the United States. Under specific circumstances, nonimmigrant workers have been allowed legal access to the American labor market. They should not be confused with illegal immigrants who do not have such a privilege. The legislative and administrative actions that have authorized non-immigrant programs traditionally have been shrouded in controversy. Policy concerns have centered upon both the economic effects of non-immigrant workers on working conditions for citizen workers and the special restrictions often imposed on non-immigrants that would be considered unfair and often illegal if applied to citizen workers.

Included among the various reforms of the nation's irnmigration system for the 1980s have been a host of proposals to alter the role of nonimmigrant policy. It has been suggested that the policy can serve as a means to overcome specific labor shortages and to reduce the general problem of illegal immigration. To understand its potential to accomplish these goals, it is necessary to place non-immigrant policy in an evolutionary context. For if we examine isolated events at different points in history, the policy seems to be merely ad hoc reactions to those events of a particular time. A long-term perspective, however, reveals developmental patterns. Recognition of these themes and characteristics is essential to any effort to evaluate the efficacy of contemporary non-immigrant policy as well as the pending proposals that call for an expansion of such endeavors.

The author is Professor of Labor Economics, Cornell University. 


\section{The Antectem Programs: The Pre-1952 Experience}

The initial effort to establish by law the right of American employers to recruit and hire foreign labor to work in the United States was the Contraet Labor Act of $186+$. Enacted as a wartime measure, it was repealed in 1868 although private groups continued the practice with little interruption for many years afterward. During most of this period, the nation had essentially an open immigration policy to anyone except the Chinese. Thus, technically speaking, the contract labor era does not represent a non-immigrant program. Those persons who were recruited were encouraged to stay as permanent immigrants. Although the Alien Contract Law finally banned contract labor in 1885 , its principles laid the conceptual foundation for subsequent non-immigrant programs.

Only months after the United States enacted the most restrictive immigration legislation in its history up until that time-the Immigration Act of 1917-it initiated the first publicly sanctioned foreign labor program.' In response to strong pressure from the large agricultural growers of the Southwest, Congress included in the act a provision that would allow entry of "temporary workers" from Western Hemisphere nations who were "otherwise inadmissible," In May 1917, with the nation at war, Congress authorized such a temporary farm worker program with Mexico. Under its terms were rules designed to protect both eitizen workers and Mexican workers as well as to assure that the Mexicans returned home after completing their work. But, as has hecome the historic pattern with these types of programs, "these elaborate rules were unenforced."

The United States enacted this temporary worker program during World War I as being in the national interest. It was subsequently extended until 1922. It ended when its rationale as a national defense policy could no longer be maintained. Also, organized labor contended that the program undermined the economic welfare of citizen workers. Other critics believed that there were no labor shortages but only opportunistic employers who wished to tap a secure source of cheap and docile workers for their own private gain. During the lifespan of the program, 76,862 Mexican workers were admitted to the United States, of whom less than half returned to Mexico."

\section{The Mexican Labor Program}

With the coming of World War II, the military manpower requirements of the United States and its related manufacturing labor needs led to assertions that another labor shortage existed in the agricultural sector. 
The growers of the Southwest had foreseen these developments and in 1941 they unsuccessfully requested another contract labor program by the federal government. By mid-1942, however, the government had come to favor the program, but the government of Mexico balked at the prospect of a formal inter-governmental agreement. The unregulated hiring of Mexican citizens by foreign nations is prohibited by the Mexican Constitution of $1917 .^{4}$

Negotiations between the two governments ultimately resulted in a formal agreement in August 1942 that launched the Mexican Labor Program-more popularly known as the "bracero program." Under its terms, Mexican workers were allowed to work in agricultural jobs in the United States and they were to be afforded numerous protections with respect to housing, transportation, food, medical needs, and wages. Included within an omnibus appropriations act known as P.L. 45, the program was extended by subsequent enactments until December 31, 1947. It continued informally and without regulation until 1951. In that year, under the guise of another war-related labor shortage, the bracero program was revived by P.L. 78.

Under P.L. 78, Mexican workers could be contracted for work in the United States. Employers were required to pay the prevailing agricultural wage, to provide free housing, to provide adequate meals at a reasonable charge, and to pay all transportation costs from the work site to the government reception centers near the border. Employers seldom met these requirements. ${ }^{6}$ Braceros were exempt from both social security and income taxes, which meant that they received more income than would a citizen worker employed at the identical money wage rate. The scale of the program can be seen in Table 1 .

In Mexico, the national government determined the actual allocation process by which the number of workers were to be chosen from among several of its states. The state governments, in turn, made similar decisions for their cities and other political subdivisions. The Mexican government sought to distribute the job opportunities geographically rather than to simply select workers from the available labor pools in the border towns. Otherwise, it feared there might be a mass internal migration to the border region. There were far more applicants in every recruiting center than there were available slots. Favoritism and bribery in the selection process became widespread.

The bracero program demonstrated precisely how border labor policies can adversely affect citizen workers in the United States-especially, in this case, the Chicanos who composed the bulk of the southwestern agricultural labor force. Agricultural employment in the Southwest was re- 
Table 1. Foreign Workers Admitted for Temporary Employment in $U . S$. Agriculure by Vear and Nationality 1942-1979a

\begin{tabular}{|c|c|c|c|c|c|c|}
\hline Year & Total & Mexican & $\begin{array}{l}\text { British West } \\
\text { Indies (includ- } \\
\text { ing Bahamas) }\end{array}$ & Canadian & $\begin{array}{l}\text { Japanese } \\
\text { and } \\
\text { Filipino }\end{array}$ & Spain \\
\hline 1942 & 4,203 & 4,203 & - & - & - & - \\
\hline 1943 & 65,624 & 52,098 & 13,526 & - & - & - \\
\hline $19+4$ & 83,206 & 62,170 & 19,622 & 1,414 & - & - \\
\hline 1945 & 72,900 & 49,454 & 19.391 & 4,055 & - & - \\
\hline 1946 & 51,347 & 32,043 & 13,771 & 5,533 & - & - \\
\hline 1947 & 30,775 & 19,632 & 3,722 & 7,421 & - & - \\
\hline 1948 & 44,916 & 35,345 & 3,671 & 5,900 & - & - \\
\hline 19.49 & 112,765 & 107,000 & 2,765 & 3,000 & - & - \\
\hline 1950 & 76,525 & 67.500 & 6,225 & 2.800 & - & - \\
\hline 1951 & 203,640 & 192,000 & 9,040 & 2.600 & - & - \\
\hline 1952 & 210,210 & 197,100 & 7,910 & 5,200 & - & - \\
\hline 1953 & $21,5,321$ & 201,380 & $7,7+1$ & 6,200 & - & - \\
\hline 1954 & 320,737 & 309,033 & 4.704 & 7,000 & - & - \\
\hline 1955 & 411,966 & 398,650 & 6.616 & 6,700 & - & - \\
\hline 1956 & 459,850 & 445,197 & 7,563 & 6,700 & 390 & - \\
\hline 1957 & 452,205 & $+36,0+9$ & 8,171 & 7,300 & 685 & - \\
\hline 1958 & 447,513 & 432,857 & $7,4+41$ & 6,900 & 315 & - \\
\hline 1959 & 455,420 & $437,6+3$ & 8,772 & 8,600 & 405 & - \\
\hline 1960 & 334.729 & 315.846 & 9.820 & 8,200 & 863 & - \\
\hline 1961 & 310,375 & $291,+20$ & 10,315 & 8,600 & 40 & - \\
\hline 1962 & 217,010 & 194,978 & 12,928 & 8,700 & 404 & - \\
\hline 1963 & 209,218 & 186,865 & 12,930 & 8,500 & 923 & - \\
\hline 1964 & 200,022 & 177,736 & 14,361 & 7,900 & 25 & - \\
\hline 1965 & 35.871 & $20,28+$ & 10,917 & 4,670 & 0 & - \\
\hline 1966 & 24,080 & 8,647 & 11,194 & 3,683 & 0 & 477 \\
\hline 1967 & 23,959 & 6,125 & 13,578 & 3,900 & 0 & 356 \\
\hline 1968 & 13,704 & 0 & 10,723 & 2,600 & 0 & 381 \\
\hline 1969 & 16,221 & 0 & 13,530 & 2,300 & 0 & 391 \\
\hline 1970 & 17,937 & 0 & 15,470 & 2,004 & 0 & 463 \\
\hline 1971 & 14,235 & 0 & 12,143 & 1,541 & 0 & 551 \\
\hline 1972 & $12,8+7$ & 0 & 11,419 & 1,107 & 0 & 321 \\
\hline 1973 & 13,551 & 0 & 11.712 & 1,458 & 0 & 381 \\
\hline 1974 & 14,197 & 0 & 11,625 & 1,250 & 0 & 322 \\
\hline 1975 & 12,426 & 0 & 11,245 & 970 & 0 & 211 \\
\hline 1976 & 12,325 & 0 & 11,568 & 572 & 0 & 185 \\
\hline 1977 & 12,266 & 0 & 11,661 & 399 & 0 & 206 \\
\hline 1978 & 11,581 & 0 & 10,955 & 312 & 0 & 274 \\
\hline 1979 & 12.791 & 0 & 12,246 & 287 & 0 & 258 \\
\hline
\end{tabular}

"Due to carryover of workers from one year to another, the number of workers admitted each year is generally lower than the actua! number of persons employed during peak harvest seasons.

Sources: Data for the years 1942 through 1972 are from United States Senate, 
Committee on the Judiciary, "The West Indies (BWI) Temporary Alien Worker Program 1943-1977" (Washington: U.S. Government Printing Office, 1973), Table 2, p. 27; data from 1973 through 1979 are from the U.S. Department of Justice, Statistical Yearbook of the Immigration and Naturalization Service, 1979, Table 18.

moved from competition with the non-agricultural sector. At the program's peak, almost half a million braceros were working annually in the agricultural labor market of the Southwest. The availability of Mexican workers significantly depressed existing wage levels in some regions, modulated wage increases that would have occurred in their absence, and sharply compressed the duration of the employment period during which many citizen farm workers could find jobs. ${ }^{7}$ The thorough report on the bracero program by the President's Commission on Migratory Labor in 1952 found, with respect to wage trends for agricultural workers during the bracero era, "that wages by States were inversely related to the supply of alien labor." Citizen farmworkers in the southwest simply could not compete with braceros. Braceros were totally subject to the unilateral demands of employers. For this reason, they were especially appealing workers to employers. There were also numerous charges that employers either ignored or circumvented the provisions for the protection of wage rates and working conditions. ${ }^{9}$ The bracero program was also a significant factor in the rapid exodus of rural Chicanos between 1950 and 1970 to urban U.S. labor markets, where they were often poorly prepared to find employment and housing. ${ }^{10}$

The drive to repeal P.L. 78 was led by the AFL-CIO, various Chicano groups, and an array of other community organizations generally concerned with the welfare of low income workers. Arguing that in southwestern agriculture, the prevailing wage was in fact set by the braceros themselves rather than by domestic labor market factors, the Kennedy Administration promised in 1961 that much tighter administrative regulations would be imposed. Beginning in mid-1962, the Department of Labor set an "adverse-effect wage rate" for each state. These were minimum wage rates that the Department determined had to be paid to prevent braceros from adversely affecting what would otherwise be marketdetermined wages for citizen agricultural workers. In most cases, the adverse wage rates were set higher than the prevailing wages. The adverse wage, however, had to be offered to citizen workers if the agricultural employer intended to seek foreign workers. Under these terms, the bracero program lost much of its attractiveness to employers. The bitter political struggle over the program came to an end with the termination of the program on December 31, 1964. The only supporter of the program at the time was the Department of State, which believed that "the program has 
been beneficial to Mexico" and warned that even if the program were terminated, Mexican workers would likely continue to come anyhowalbeit illegally. ${ }^{11}$ This same conclusion was drawn by the Mexican government, which feared that the braceros had been exposed to the wages and working conditions of the United States and were unlikely to be content with the poorer opportunities at home. ${ }^{12}$ In fact, the acceleration in the rate of illegal immigration from Mexico can virtually be dated to the termination of the bracero program.

\section{The British West Indies Labor Program}

Following the preedent set by the Mexican Labor Program, the governments of the British West Indies (including Jamaica, St. Lucia, St. Vincent, Dominica, and Barbados) and the Bahamas also entered into an intergovernmental agreement with the United States in April 1943 to create a non-immigrant program to supply agricultural workers. Known as the British West Indies Program (BWI program), it was designed as a response to concerns by employers along the East Coast that they too were experiencing wartime labor shortages. As most BWI workers spoke English, they had an advantage to employers over the Mexican workers available in the bracero program.

Like the bracero program, the BWI program was formalized on the basis of P.L. 45 from 1943 through 1947. Although the aggregate numbers were small-about 24,000 a year-when compared to the bracero program, BWI workers were a substantial part of the particular agricultural labor markets in which they were employed. ${ }^{1:}$ The BWI program, however, did permit some employment in non-agricultural work during the war years. ${ }^{14}$ From 1947 to 1952, the BWI program was re-converted into a temporary agricultural worker program as allowed under the Immigration Act of 1917.

A review of the BWI program by a presidential commission in 1952 condemned the program's administration. In particular it attacked the lack of "vigilance for the protection of living and working standards" of the workers. ${ }^{15}$

\section{Policy Dex'elopment: The Post-1952 Experience}

In 1952, the Immigration and Nationality Act recodified and revised the nation's prevailing immigration law. In the process, it repealed the Alien Contract Labor Act of 1885 with its ban on contract labor. All persons entering the nation had to be classified as being either immigrants 
or non-immigrants. But the concept of non-immigrants became infinitely more complex. The act specified twelve classes of non-immigrants-each divided into subclasses. An unofficial convention has evolved whereby the individual classes and subclasses are identified by the letters and numbers of the section of the act. Several classes cannot work in the United States (for example, visitors for pleasure or aliens in transit); others can work in the United States but their work has little or no impact on the U.S. labor market (for example, foreign ambassadors, or officials of international organizations, or representatives of foreign news media); others do work directly in the labor force. ${ }^{16}$ Table 2 indicates the non-immigrant

Table 2. Numbers of Non-Immigrants Admitted to the United States in Immigration Categories That Are Permitted to Work, Fiscal Year 1978

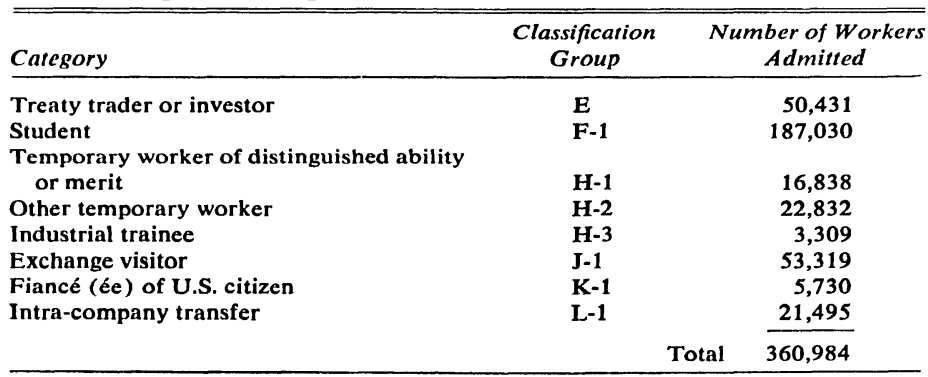

SOURCE: U.S. Department of Justice, Annual Report of the Immigration and Naturalization Service: 1978 (Washington, D. C.: U.S. Government Printing Office, 1979), Tables 16 and 16B.

categories permitted to work legally and the corresponding number of admissions in 1978 for each classification.

Among the non-immigrants permitted to work as part of the regular labor force are several classifications free to change jobs at will. They are not linked contractually to employers. Among these, for instance, are foreign students who may legally work (F-1 workers) in any occupation if they receive permission from the Immigration and Naturalization Service (INS). Most of the others are under some form of binding contractual obligations to their employers. Among these are H-1 workers (persons of distinguished merits and ability - such as opera singers, actors, and various professional workers); $\mathrm{J}-1$ workers (exchange visitors in various international programs); and L-1 workers (intra-company trans- 
ferees of multi-national corporations). Most of these workers are in whitecollar occupations or other highly skilled jobs.

It is the H-2 program for "other temporary workers," however, that has generated most of the controversy. In $196969,288 \mathrm{H}-2$ workersthe largest number ever-were admitted. The number has since declined and leveled off to around 23,000 a year. Table 3 indicates the occupa-

Table 3. Occupations of All Non-Immigrant H.2 Workers Admitted to the United States During Fiscal Year 1978

\begin{tabular}{lr}
\hline Occupation & Number Admitted \\
\hline Professional and technical & $\mathbf{8 . 4 0 6}$ \\
Managers and administrators & 170 \\
Sales workers & 103 \\
Clerical workers & 135 \\
Craft workers & 2,845 \\
Operatives (except in transportation) & 298 \\
Transportation operatives & 97 \\
Non-farm laborers & 1,585 \\
Farmers and farm mangers & 0 \\
Farm laborers and foremen & $\mathbf{8 . 3 0 6}$ \\
Service workers (except private household) & 511 \\
Private household workers & $\mathbf{3 7 6}$ \\
& $\mathbf{2 2 , 8 3 2}$ \\
\hline
\end{tabular}

Source: U.S. Department of Justice, Annual Report of the Immigration and Naturalization Service: 1978 (Washington, D.C.; U.S. Government Printing Office, 1979), Table 16B.

tional distribution of all $\mathrm{H}-2$ workers in 1978. Within the H-2 classification, the largest single occupation has generally been farm workers. ${ }^{17}$ As the size of the program has declined, the proportion of the total who are agricultural workers has risen to more than one-third of all H-2 workers.

The non-agricultural $\mathrm{H}-2$ workers are occupationally dispersed. The largest group are professional and technical workers, generally people "of lower status than those entering on $\mathrm{H}-1$ visas" or exchange visitors. ${ }^{18}$ Most of these are writers, artists, and entertainers, followed by athletes and musicians.

Supposedly, H-2 workers can be admitted only "if unemployed persons capable of performing such service or labor cannot be found in this country." It is up to the Department of Labor to decide whether citizen workers are available. In making its determination, the department applies the system of "adverse wage rates." The final entry decision, however, resides not with the Department of Labor but rather with the Department 
of Justice. Frequently, the latter overrules the former's decisions against admission.

H-2 workers do not pay social security taxes, which means that the employer does not deduct the tax from the employee's wage nor does the employer have to match the tax, as is the case with citizen workers. $\mathbf{H}-\mathbf{2}$ workers are also exempt from unemployment compensation taxes on employer payrolls. Hence, an employer may secure $\mathbf{H}-2$ workers at wage costs below those paid to citizen workers even when the nominal rates are the same to both.

Although many non-agricultural $\mathrm{H}-2$ workers enter under contractual terms that tie them to specific employers, their wages and working conditions are not controversial nor are they seen as any threat to citizen workers. The same cannot be said for the agricultural $\mathrm{H}-2$ workers or for the use of the entire $\mathrm{H}-2$ worker program in the territories of Guam and the Virgin Islands. These cases require brief elaboration.

\section{Agricultural H-2 Workers}

The H-2 program in agriculture incorporates all of the undesirable features of its forerunner, the bracero program. Workers are totally dependent upon their employers. Eligibility for the program often depends upon one's contacts with certain officials of one's home government. It is often considered a privilege to be selected. Corruption in the selection process is rampant. If chosen, the worker can be assured of the opportunity to return again only if his work and attitude please the U.S. employer. This is because the employer may "request by name" a set proportion (usually 50 percent) of this year's $\mathrm{H}-2$ workers to return the next year. In effect, the workers must compete with one another on terms very favorable to the employer. If at any time the worker's demeanor is deemed unsatisfactory by his employer, the worker may be deported without an appeal. Given this system, "it is little wonder that $\mathrm{H}-2$ aliens are "hard working and diligent." "19

Although several countries are involved as sources of agricultural $\mathbf{H}-2$ workers, about 90 percent of their annual numbers are from the British West Indes (predominantly Jamaica). Their involvement as $\mathbf{H}-\mathbf{2}$ workers is a continuation of the aforementioned BWI labor program, which was assumed into the H-2 program in 1952. Throughout the 1950s, the use of BWI workers increased, but the BWI was still small in comparison to the co-existing bracero program. Hence the BWI program escaped close scrutiny. When the bracero program was phased out in the early 1960s, attention turned to the BWI program. The programs were so similar in 
structure that the same arguments that led to the termination of the bracero program seemed logically to apply to the BWI program. The Department of Labor did issue more restrictive regulations in the early 1960 s and again in the late 1970 s for all H-2 workers.

The employers of $\mathrm{H}-2$ agricultural workers have contended that the major alternative to $\mathrm{H}-2$ workers is illegal immigrants. Illegal immigrants have been involved in East Coast agriculture but the incidence is believed to be much less than has been the case in agriculture in the Southwest. East Coast employers claim that it was the termination of the bracero program in the Southwest in $196+$ that led to the widespread use of illegal immigrants in that region." They also contend that it is difficult to attract citizen workers to these seasonal occupations. ${ }^{21}$

\section{The Virgin Islands Program}

The series of fifty islands that comprise the Virgin Islands have belonged to the United States since their purchase from Denmark in 1917. At the time, free travel to find employment was traditional throughout the Caribbean region. This practice continued until 1938 when the U.S. government ruled that the prevailing immigration statutes applied to the islands. All aliens who resided in the islands as of 1938 were ruled to be legal resident aliens. During World War II, there was a need for unskilled workers to build up the defense forces on the island of St. Thomas to protect the Panama Canal. Workers from nearby French and British islands were allowed to work on these projects. For reasons of expediency, they were permitted to stay when the war ended,

The enactment of the H-2 provisions in 1952 laid the groundwork for ratification of the process already begun. In 1956, a temporary worker agreement was reached between the United States and the nearby British Virgin Islands. In 1959, the agreement was extended to include the many other islands of the British, French, and Dutch West Indies. These H-2 workers were supposed to be employed only in the agricultural and tourist industries. Pro forma efforts were made to see if citizen workers were available, but, in fact, by the early 1960s admission was permitted "for any job." 22 By the end of the 1960 s, "alien labor constituted roughly half of the Virgin Islands labor force." Before long, problems of housing, education, and social conditions for $\mathrm{H}-2$ workers had become so "terrible" that the H-2 workers had become "the biggest single problem" on the islands. ${ }^{2+}$ It was even feared that if the status of these workers changed from $\mathrm{H}-2$ to resident aliens that the native-born population could lose political control of the islands. 
By the 1970s, it was obvious to the Department of Labor that "the nonimmigrant aliens virtually determined the prevailing wage in many occupations."25 The department, therefore, issued indefinite labor certificattions to these $\mathbf{H}-2$ workers and allowed them to change jobs freely. It would no longer make any effort to see if citizen workers were available. All pretense to the existence of a temporary work program was abandoned.

\section{The Guam Labor Program}

The island of Guam was ceded to the United States in 1898 as part of the treaty ending the Spanish-American War. Because of its strategic location in the mid-Pacific, it has remained a key military installation for the United States. The Immigration and Nationality Act of 1952 was the first immigration statute to apply to Guam.

During World War II, Guam was devastated. When the rebuilding process began, many residents sought jobs with the federal government because the private economy had been virtually destroyed. Against this backdrop, the government introduced a non-immigration labor program. Most of these foreign workers were admitted to do construction work. In May of 1947, workers from the Philippines and other islands were hired under short-term contracts. ${ }^{21}$ In 1952, the status of these contract workers came into immediate conflict with the newly enacted H-2 provisions. Not only were these workers in a variety of occupations but many had been in Guam for a number of years. They were not "temporary workers." Nonetheless, accepting the contention of the U.S. Navy that they were needed for defense purposes, the INS granted all blanket H-2 status in 1953.

Criticism mounted that $\mathbf{H - 2}$ workers on Guam were receiving "slave wages." 27 There were also charges of extensive racketeering among the labor recruiters in the Philippines involving wage kickbacks and bribery in the selection process. Consequently, the INS announced in 1958 that the program for non-defense employers would be phased out. In 1960, the INS also decided to end the $\mathbf{H - 2}$ defense worker program. It feared that the H-2 arrangement was becoming a permanent part of the Guam economy and that few efforts were being made to train citizen workers for the jobs held by $\mathrm{H}-2$ workers. In its place, however, non-immigrant workers continued to be admitted under the separate parole authority given to the Attorney General under the Immigration and Nationality Act to admit people temporarily for "emergent reasons" or reasons deemed to be in the "public interest." 28 In response to requests by defense contractors and the military on the island, non-immigrant workers from the 
Philippines were again admitted until 1975. The INS instituted a second parole program in 1962 for temporary workers to do reconstruction work after the island was hit by a severe typhoon. This program was terminated in May 1970 when the INS decided that the H-2 program was more appropriate for construction workers than the parole procedures. ${ }^{2 n}$

The revival of the $\mathrm{H}-2$ program on Guam came in response to employer claims of labor shortages as a result of the expanding tourist industry in particular and the island's population growth in general. The government of Guam also sought H-2 workers as a means of developing new industries-especially in agriculture and fishing. During the 1970 s, the longstanding problem of many $\mathrm{H}-2$ workers not complying with the terms of their admission surfaced. In other words, H-2 workers were overstaying their visas and becoming illegal immigrants. ${ }^{30}$

By 1977 a Department of Labor report on labor market conditions on Guam described them as heing "abysmal." 31 The report noted that by 1976 one-sixth of the island's civilian labor force was H-2 workers. Moreover, H-2 workers made up 82 pereent of all persons employed in construction, 47 percent of agricultural workers, and 15 percent of workers in manufacturing. ${ }^{32}$ With reference to the working conditions, the report cited numerous examples of worker abuse by employers and labor recruiters. It also detailed the Labor Department's inability to enforce existing labor standards in an environment in which workers were completely beholden to their employers. The H-2 workers, under these circumstances, had become preferred workers for employers. Citizen workers could not compete with them on their terms, leading to a higher rate of unemployment for citizens. As the report noted, "alien workers constitute such a large proportion of the work foree that the wages at which they are certified are the prevailing wage rates. "ial It noted that the wages and working conditions were being set not by a free market but rather as a result of government policy.

\section{A New Role For Non-Immigrant Horkers}

Beginning in the 1970 s and continuing into the early 1980 s, policy makers have suggested an entirely new role for the nation's non-immigrant labor policy. As illegal immigration became a national issuc, students of the issue suggested that a non-immigrant program be included among the policy options to overcome this problem. Some advocated creation of a new non-immigrant labor program; others argued for expansion of the existing $\mathrm{H}-2$ program in an effort to absorb and to legalize the work done by many illegal immigrants. ${ }^{3+}$ 
Implicit in all of the proposals was the assumption that most illegal immigrants do work shunned by citizen workers. It was argued that the non-immigrant workers would not affect the wages and working conditions of citizen workers since they would-by virtual definition-not compete for the same jobs. None of these proposals contained any historical review of the nation's past experiences with non-immigrant programs. As a result, they are all merely conceptual programmatic sketches. None scratched the surface of such critical issues as how the workers are to be recruited; what their job entitlements are; what the limitations to be placed on employer prerogatives to limit exploitation are; what the means used to test for job certification are to be; and what protections assuring that prevailing standards for citizen workers and for unions will not be undermined are to be included.

In August 1977, the Carter administration included within its immigration reform package an explicit charge that the $\mathrm{H}-2$ program be given a comprehensive review. ${ }^{35}$ Although explicitly denying any interest in a bracero program, the administration implied that an expanded temporary work program might meet the needs of some employers while not adversely affecting citizen workers. After studying the proposal, the Commission for Manpower Policy advised President Carter that it was "strongly against" any expanded $\mathbf{H}-2$ program. ${ }^{36}$

Rather than act directly upon the Carter administration's immigration proposals, Congress established the Select Commission on Immigration and Refugee Policy to study all dimensions of the nation's immigration policy. In its subsequent report, the commission acknowledged that the H-2 program has been the source of significant criticism. Nevertheless, the Select Commission concluded that "a continuation of the program is necessary and preferable to the institution of a new one." 37 It made several suggestions to "streamline" the administration of the program. It recommended that employers be required to pay both social security and unemployment compensation payroll taxes on all $\mathrm{H}-2$ workers in order to remove "inducements to hire $\mathbf{H - 2}$ workers over U.S. workers." 38 The commission specifically concluded that there should not be any new temporary worker program established as part of any strategy to combat illegal immigration. ${ }^{30}$

By the time the Select Commission issued its report in 1981, the Reagan Administration had taken office. That administration formed a task force chaired by the Attorney General to study the commission's recommendations. When the task force released its response in July 1981, it made no mention of the $\mathbf{H}-2$ program but did propose that a new "experimental temporary worker program for Mexican nationals" be established. ${ }^{40}$ The 
"pilot program" would be for a two-year trial period and would be limited to 50,000 workers each year. If the concept proved workable it could be expanded to a million or so foreign workers in subsequent years. ${ }^{+1}$

In response to the Select Commission's Report and the Reagan Administration's proposals, Congress held extensive hearings in the fall of 1982 on all facets of the nation's immigration policy. A result was a bipartisan bill called the Immigration Reform and Control Act of 1982 (the Simpson-Mazzoli bill)."2 It overwhelmingly passed the Senate in August 1982 but died on the floor of the U.S. House of Representatives during the waning hours of the 97th Congress. Differences over the role of the $\mathbf{H - 2}$ program was one of the major reasons that this important bill was not enacted. t: It proposed that the Department of Agriculture become involved in the administration of the $\mathrm{H}-2$ program for farm workers. It also proposed that the Department of Labor be required to expedite requests by employers for $\mathrm{H}-2$ workers in any industry. As there is no ceiling on the number of $\mathrm{H}-2$ workers that can be admitted, opponents to the $\mathrm{H}-\mathbf{2}$ program feared that these and other changes would lead to a "backdcor bracero program" of upwards of 500,000 non-immigrant workers.

\section{An Assessment of the "New" Role for \\ Non-Immigrant Labor Programs}

As should be apparent from this review of the evolution of non-immigrant labor policy, using it as a means of combatting illegal immigration (a labor supply problem) would be a departure from its historic role (as a labor demand policy). Contemporary interest in non-immigrant worker programs is not based on the existence of a demonstrated need for such workers. The proposals for new or expanded non-immigrant labor programs are designed to supply more workers for unskilled and semi-skilled occupations in primarily low-wage industries. These are precisely the same labor markets in which those subgroups of the labor force with the highest unemployment rates in the nation are already found in disproportion. No one is suggesting that there be a foreign worker program to supply more workers for white-collar occupations. Not only would such proposals lead to charges of a "brain drain" from source nations, but also the opposition of the privileged and protected workers in domestic labor markets could be counted upon to kill any such idea at the moment of its conception.

Supporters of a new or expanded non-immigrant worker program for the United States often assert that citizen workers will not do the types of low-wage jobs that non-immigrants and illegal immigrants perform. ${ }^{4+4}$ 
Hence, they conclude that there will be no adverse effects on the domestic larbor force. Except for scattered anecdotes, no empirical evidence has been collected to support this view. In fact, there is ample evidence that illegal immigrants do compete directly for jobs in occupations that also attract millions of citizen workers. ${ }^{45}$ No one can seriously argue that citizens are unavailable for certain types of jobs when each day the majority of persons who work in these occupations are citizen workers. The U.S. Department of Labor estimated that in 1981 there were 29 million workers (or 30 percent of the employed labor force) employed in "the kinds of low-skilled industrial, service, and agricultural jobs in which illegal aliens typically seek employment." 4 It also estimated that 10.5 million workers were employed in jobs that paid the federal minimum wage ( $\$ 3.35$ an hour) and that an additional 10 million workers were receiving only 30 to 40 cents per hour more than the minimum wage. For the contentions of the advocates of new or expanded non-immigrant worker programs to be valid, they must be willing to argue that there will be too few citizen workers available no matter what the wages or benefits associated with certain occupations in the American economy.

The presence of non-immigrant workers affects not only job opportunities but also wage levels in any given labor market. It is these wage effects that are part of the attractiveness of both non-immigrant workers and illegal immigrants to American employers. Employers are able to obtain workers in selected labor markets at less cost than would be the case in their absence. It is also probable that foreign workers in lowwage American industries are less likely to make demands for job rights or to join unions.

Another flaw in these proposals is their intended magnitude. An expanded non-immigrant program cannot do anything to reduce illegal immigration unless the program is significantly large (at least in the 500,000 - to 750,000-person range each year). But the larger the program, the greater the likelihood of adverse impact on citizen workers in selected labor markets. On the other hand, if the scale of the program is small, where will the deterrence to illegal entry be? Politically, if not economically, speaking, there must be some limitations on the size of the program. If there is, what will stop others who are not selected from coming, or others, whose period of work has expired but who wish to remain, from staying? A new or expanded non-immigrant labor program does not resolve any of the prevailing problems with the nation's immigration policies while it adds a host of new ones.

Moreover, most of the advocates of new non-immigrant programs assume either implicitly-or explicitly in the case of the Reagan plan-that 
the program would be a bilateral arrangement with Mexico. But illegal immigrants are streaming into the United States from many countries other than Mexico. If the program were restricted to Mexicans, it would do nothing to reduce the flows from these other nations that, collectively. account for about one-half of all illegal immigration.

One specific study has sought to examine the alleged need for foreign workers from the viewpoint of American employers. ${ }^{47}$ Conducted in San Diego, California, in 1981, it sought to discover if employers could pay the higher, competitive wages needed to attract citizen workers to certain industries in which illegal immigrants were widely used. Employers in agriculture, restaurants, and electronic manufacturing in San Diego were interviewed. Consistently, the employers lauded illegal immigrant workers over citizen workers. But rather than rely simply on the attitudes of employers, the study also investigated whether employers would be forced to go out of business or, in some eases, to relocate south of the border if they had to compete actively for eitizen workers. Employers were not asked if they were willing to pay a prevailing wage, but rather, "at what wage would you go out of business if you had to raise wages in order to attract U.S. workers?" The study found that the ceiling wage indicated by employers was sufficiently high to attract citizen workers but that the employers preferred the more profitable low wages that they could offer to foreign workers. As a result, the study concluded that labor displacement was occurring in the San Diego labor market. ${ }^{+*}$ Hence, the study concluded that "a foreign-worker program would simply legitimize this strategy. "4n

The past experience of the nation with non-immigrant labor programs in low-wage industries has revealed another pernicious long-run effect of their operations. Namely, when workers come from economically less developed countries to the United States, they are made aware of opportunities that for many are beyond their previous imagination. The relatively higher wages and the broader array of job opportunities will cause many to find ways to remain. Rather than being an alternative to illegal immigration, these policies can-as history has repeatedly shown--become a method that fosters the phenomenon.

It should not be surprising that among the strongest voices in opposition to proposals to expand temporary worker programs have been those from groups closely associated with the protection of opportunities for low-wage workers. For example, a 1979 conference on "Jobs for Hispanics"-sponsored by the Labor Council for Latin American Advancement and attended by both Hispanic trade unionists and Hispanic community groups from across the country-took a strong and unanimous 
stand against a foreign worker program. In their conference manifesto, called the "Declaration of Albuquerque," they emphatically stated: "The federal government should not include any type of 'Bracero" program or foreign labor importation as a solution to the current problem of undocumented workers." So Similar strong statements of opposition to any type of new or expanded temporary foreign worker program were made to the Select Commission by the National Hispanic Task Force (a group representing eight of the nation's largest Hispanic organizations), and by such groups as California Rural Legal Assistance, Texas Rural Legal Aid, Inc., and the National Center for Immigrants' Rights. ${ }^{61}$ All of these organizations have a long history of dedicated support for the low-income workers who would bear the brunt of the competition for jobs from foreign temporary workers.

When the Reagan administration announced in 1981 its support for a new foreign worker program, it was met by a chorus of opposition. The administration may have anticipated that the AFL-CIO would attack the proposal as being a mechanism for employers to find "a docile and controllable work force."52 It was totally unexpected, however, that the Mexican labor movement, the Confederacion de Trabajadores de Mexico (CTM), would also strongly condemn the idea. In a "Manifesto to the People," the president of CTM, Fidel Velasquez, said that the Reagan proposal would convert Mexican workers into "the biggest strategic labor reserve in contemporary history, subject to super-exploitation and servitude." 53 The fact that CTM is an integral part of the Party of Revolutionary Institutions (PRI), which has solely controlled Mexican political affairs since a few years after the Mexican revolution in 1917, meant implicitly that it was speaking for the Mexican government. Officially, the Mexican government did not comment on the Reagan proposal but it is inconceivable that CTM would speak out publicly in opposition to the plan if it did not represent the consensus view of PRI.

Likewise, one of the strongest critics of the proposed H-2 changes embodied in the aforementioned Simpson-Mazzoli bill was the Mexican American Legal Defense and Education Fund. Its president charged in October 1982 that "the Simpson-Mazzoli $\mathrm{H}-2$ program is really just a replay of the bracero program" and that its provisions would actually "foster" illegal immigration just as the old program did. ${ }^{54}$

\section{Concluding Observations}

There are features of the nation's non-immigrant labor policies that are both logical and beneficial to the economy and the quality of life of the 
nation. Yet within the broad dimensions of non-immigrant labor policy there has also been a programmatic history that is not so easy to rationalize. It has usually involved the employment of workers less skilled and less talented than those generally available within the American labor force but who are, nonetheless, similar in their employment capabilities to certain large segments of the American labor force. These instances challenge the sanguine attitude surrounding non-immigrant labor policy. For as the history of these endeavers reveals, there has been a persistent theme of misuse and abuse. Because these non-immigrant workers are unskilled and from relatively impoverished backgrounds, they are easy prey for a corrupt selection process in their home nations over which the United States has little control. Once in the United States, these workers are often subject to working conditions that they may perceive to be desirable (relative to the alternatives in their homelands) but which affect the attractiveness of the jobs to citizen workers. To the digree that the prevailing working standards begin to deteriorate as employers hire nonimmigrant workers, citizen workers gravitate elsewhere and become less available. Employers soon not only become dependent on non-immigrant workers but also come to prefer them.

As a predictable consequence, non-immigrant programs for less skilled and less talented workers are consistently implemented under the guise of temporary worker programs. But, as past experience in the United States and in Europe has demonstrated, these programs for low-wage workers become long-term sourees of labor supply. ${ }^{55}$ They become an institutionalized phenomena that exerts a narcotic influence on all parties involved in the employment process. Employers, foreign workers, and the governments of source countries become addicted. The rationale for their existence becomes lost in the reasoning process that justifies their continuation over time. Originally, non-immigrant programs were created only during war emergency periods, but they traditionally continued long after the wars were over. With the advent of the $\mathbf{H}-2$ program, they have become a feature of peacetime, too, and there have been persistent proposals to expand their size and scope.

Non-immigrant worker programs in low-wage industries have been of interest to employers primarily as a means of reducing their costs of production and enhancing their control over their workers. Non-immigrant low-wage workers are attractive largely because of their dependence upon their employers. Citizen workers who compete with these non-immigrant workers find that their existing working conditions usually either become frozen or decline. Under few circumstances will they improve. Efforts to establish unions are made more difficult. Moreover, it is likely that if em- 
ployers were forced to rely on citizen workers they would pay more attention to worker productivity issues such as enhanced supervision, provision of job training, and redesign of jobs. These have been some of the reactions by European employers to a reduction in the number of foreign workers available to them since 1974.

Thus, non-immigrant labor policy can be seen to be a topic that has played a long and often controversial role in American immigration policy. It is likely that it will continue to do so. It is to be hoped, however, that usage of non-immigrant workers will be limited and constantly monitored. Certainly there is nothing in the programmatic history of such endeavors that would warrant their expansion under the pretext of being a cure for illegal immigration.

\section{Notes}

1. George C. Kiser and Martha Woody Kiser, Mexican Workers in the United States: Historical and Political Perspectives (Albuquerque: The University of New Mexico Press, 1979); see especially chap. 1.

2. Ibid., p. 10.

3. George C. Kiser, "Mexican American Labor Before World War II," Journal of Mexican American History 2 (Spring 1972) : 122-42.

4. Mexican Constitution of 1917, Article 123, Paragraph XXVI.

5. The word "bracero" is a corruption of the Spanish word "abrazo," which means "arms." Literally, the word bracero meant someone who works with his arms. An English equivalent might be "field hand."

6. Ernesto Galarza, Merchants of Labor: The Mexican Bracero Story (Charlotte, N.C.: McNally and Loftin, 1964); see especially chaps. 816.

7. U.S. Senate, Committee on the Judiciary, "A Report on Temporary Worker Programs: Background and Issues" (Washington, D.C.: U.S. Government Printing Office, 1980), pp. 47-51.

8. President's Commission on Migratory Labor, Migratory Labor in American Agriculture: Report (Washington, D.C.: U.S. Government Printing Office, 1951 ), p. 59.

9. Galarza, Merchants of Labor, chaps. 12, 13, 15, 16, and 17.

10. Vernon M. Briggs, Jr., Chicanos and Rural Poverty (Baltimore: Johns Hopkins University Press, 1973), p. 29.

11. U.S. Senate, Committee on the Judiciary, "A Report on Temporary Worker Programs," p. 55.

12. Ibid.

13. U.S. Senate, Committee on the Judiciary, Subcommittee on Immigration, The West Indies (BWI) Temporary Alien Labor Program: 1943-1977 (Washington, D.C.: U.S. Government Printing Office, 1978), p. 8.

14. Ibid.

15. President's Commission on Migratory Labor, Migratory Labor, p. 58.

16. David S. North, Non-immigrant Workers in the United States (Washing- 
ton, D.C.: New Trans Century Foundation, 1980); see especially chap. 1.

17. Edwin P. Reubens, Temporary Admission of Foreign Workers: Dimensions and Policies, Special Report no. 34 (Washington, D.C.: National Commission for Manpower Policy, 1979), p. 15.

18. Ibid.

19. Philip Martin and David North, "Non-immigrant Aliens in American Agriculture" (Paper presented at the Conference on Seasonal Agricultural Labor Markets in the United States, Washington, D.C., 10 January 1980 ), p. 20 (xerox).

20. U.S. Senate, The West Indies Program, pp. 37-40.

21. Perry R. Ellsworth, "Need for Seasonal Foreign Workers in Terms of Present and Projected Labor Markets" (Statement on behalf of the National Council of Agricultural Workers) U.S. Immigration Policy and the National Interest, Appendix F of the Staff Report (Washington, D.C.: Select Commission on Immigration and Refugee Policy, 1981), p. 87.

22. U.S. House of Representatives, Committee on the Judiciary, Subcommittee on Immmigration, Citizenship, and International Law, Non-immigrant Alien Labor Program on the Virgin Islands of the United States (Washington, D.C.: U.S. Government Printing Office, 1975 ), p. 15.

23. Ibid.

24. Ibid., p. 17.

25. Ibid., p. 36.

26. U.S. House of Representatives, Committee on the Judiciary, Subcommittee on Immigration, Citizenship, and International Law. The Use of T'mporary Alic'n Labor on Guam (Washington, D.C.: U.S. Government Printing Office, 1979), p. 4.

27. Ibid., p. 13.

28. Section 212 (d) (5) of the Immigration and Nationality Act of 1952.

29. U.S. House of Representatives, Temporary Labor on Guam. p. 25.

30. Ibid, , p. 49.

31. Cover letter from Walter J. Haltigan, Regional Administrator, to Floyd E. Edwards, Administrator, U.S. Department of Labor, that accompanied report entitled "Guam Allied Labor Situation," San Francisco, California, 16 May 1977, p. 1 (xerox).

32. Ibid., p. 18 of the report.

33. Ibid., p, 40 of the report.

34. See W. R. Böhning, "Regularizing Undocumentados," World Employment Programme, Working Paper no. 36 (Geneva: International Labor Organization, 1979); Wayne A. Cornelius, "Proposal for a System of Temporary Worker Migration Visas" (Cambridge: MIT Press, 1977); Charles B. Keely, U.S. Immigration: A Policy Analysis (New York: The Population Council, 1979), pp. 60-62; and Edwin Reubens, Temporary Admission of Foreign Horkers: Dimensions and Policies, Special Report no. 34 of the National Commission on Manpower (Washington, D.C.: U.S. Government Printing Office, 1979).

35. Office of the White House Press Secretary, "Message of the President to Congress on Illegal Immigration," Washington, D.C., 4 August 1977, p. 6 (mimeograph). 
36. Letter to Secretary of Labor Ray Marshall from Eli Ginsberg, Chairman of the National Commission for Manpower Policy, dated 1 May 1979, in Reubens, Temporary Admission, p. 100.

37. Select Commission on Immigration and Refugee Policy: U.S. Immigration Policy and the National Interest (Washington, D.C.: U.S. Government Printing Office, 1981 ), p. 227.

38. Ibid., p. 229.

39. Ibid., p.45.

40. U.S. Department of Justice, "U.S. Immigration and Refugee Policy," Washington, D.C., 30 July 1981 , p. 5 (xerox).

41. Joseph Nalven and Craig Frederickson, The Employer's View: Is There a Need for a Guest-Workers Program?' (San Diego: Community Research Associates, 1982), p. 1.

42. U.S. House of Representatives, "Immigration Reform and Control Act of 1982," H.R. 5872 (7 March 1982). (Also simultaneously introduced in the U.S. Senate as S.2222.)

43. For example, see Congressional Record (House), 16 December 1982, pp. H 10085-86 and 12 December 1982, pp. H 10351-53.

44. See, Böhning, Regularizing Undocumentados; Wayne Cornelius, Mexican Migration to the United States: Causes, Consequences, and U.S. Responses (Cambridge: Center for International Studies, Massachusetts Institute of Technology, 1978); and Michael J. Piore, Birds of Passage: Migrant Labor and Industrial Societies (London: Cambridge University Press, 1979); see especially chap. 2.

45. See David S. North and Marion F. Houston, The Characteristics and Role of Illegal Aliens in the U.S. Labor Market: An Exploratory Study (Washington, D.C.; Linton, 1976), and Maurice D. Van Arsdol, Jr., Joan Moore, David Heer, and Susan P. Haynie, Non-Apprehended and Apprehended Undocumented Residents in the Los Angeles Labor Market (Final Draft submitted to the U.S. Department of Labor under Research Contract No. 20-06-77-16, October 1978).

46. "Statement of Malcolm Lovell, Under-Secretary of Labor before the Subcommittee on Immigration, Refugees, and International Law, Committee on the Judiciary, U.S. House of Representatives and the Subcommittee on Immigration and Refugee Policy of the U.S. Senate," 20 April 1982, p. 3 (mimeograph).

47. Nalven and Frederickson, The Employer's View.

48. Ibid., p. 7.

49. Ibid., p. 79.

50. Labor Council for Latin American Advancement, "Declaration of Albuquerque and Employment Action Program," Conference Report of the National Conference on Jobs for Hispanics (August 1979), p. 10. (Emphasis is in the original.)

51. See "Statement by the National Hispanic Task Force," in U.S. Immigration Policy and the National Interest, Appendix $H$ to the Staff Report (Washington, D.C.: Select Commission on Immigration and Refugee Policy, 1981), p. 418, and the statements prepared collectively by the Migrant Legal Action Program and by the National Center for Immigrant Rights in Appendix F, pp. 19-84 in the same series of reports. 
52. " 'Guest Workers' Plan Assailed as Retreat on Gains," AFL-CIO News, (5 December 1981), p. 7.

53. "Mexican Labor Denounces Reagan 'Guest Worker' Plans," AFL-CIO New.s, (22 August 1981), p. 1.

54. "Simpson-Mazzoli Immigration Bill: Back to the Bracero Fiasco," The New York Times, 2 October 1982, p. A-26, a letter to the edior ftrom Joaquin G. Avila, President and General Counsel of the Mexican American Legal Defense and Education Fund.

55. Philip L. Martin, Guest-Worker Programs: Lessons from Europe, Bureau of International Labor Affairs, U.S. Department of Labor, Monograph no. 5 (Washington, D.C.: U.S. Government Printing Otfice, 1980), p. 25 . 